\title{
Differences in Male Climacteric Symptoms by Aging Male's Symptoms Scale and Coping Strategies with Aging among Rotating Night Shift Workers
}

\author{
Sachiko Kubo ${ }^{1,2}$, Toshiyuki Yasui ${ }^{3}$, Yukie Matsuura ${ }^{3} \&$ Masahito Tomotake $^{4}$ \\ ${ }^{1}$ Faculty of Nursing, Shikoku University, Tokushima, Japan \\ ${ }^{2}$ Graduate School of Health Sciences, Tokushima University, Tokushima, Japan \\ ${ }^{3}$ Department of Reproductive and Menopausal Medicine, Tokushima University Graduate School, Tokushima, \\ Japan \\ ${ }^{4}$ Department of Mental Health, Tokushima University Graduate School, Tokushima, Japan \\ Correspondence: Sachiko Kubo, Faculty of Nursing, Shikoku University, 1-123 Ebisuno, Furukawa, Ojin-cho, \\ Tokushima, Japan.
}

Received: December 11, 2021 Accepted: January 13, 2022 Online Published: January 25, 2022

doi:10.5539/gjhs.v14n3p1 URL: https://doi.org/10.5539/gjhs.v14n3p1

\begin{abstract}
The aim of this study was to clarify how male rotating night shift workers cope with male climacteric symptoms and whether coping strategies are different depending on age. A self-administered questionnaire survey regarding coping strategies in male rotating night shift workers over the age of 20 years was performed. Male climacteric symptoms were evaluated by using the Aging Male's Symptoms scale [AMS]. Of 1,891 questionnaires that were sent, 1,561 were collected. For all of the 16 symptoms, the most frequent strategy was to try to ignore and tolerate the symptoms and the second-most frequent strategy was to take time to relax. The proportions of men who ignored and tolerated psychological symptoms and sleep problems were high in all age groups. The proportions of men who ignored and tolerated the symptom of decline in the feeling of general wellbeing were high in men in their $20 \mathrm{~s}$ and low in men in their $60 \mathrm{~s}$. The proportion of men who consulted a doctor for the symptom of joint and muscular pain was high in men in their 50s. The most frequent strategy for coping with male climacteric symptoms was to ignore and tolerate the symptoms and the second-most frequent strategy was to take time to relax. There was a difference in coping behavior depending on age in rotating night shift workers.
\end{abstract}

Keywords: Male climacteric symptoms, aging male's symptoms scale, rotating night shift workers, coping strategies

\section{Introduction}

Late-onset hypogonadism [LOH] syndrome, which is induced by androgen deficiency in men, may result in deterioration in the quality of life and may adversely affect the functions of multiple organ systems. It has been reported that a low testosterone level is associated with an increased risk of bone fractures, risk of death due to cardiovascular disease, metabolic syndrome and type 2 diabetes in men (Kenny, Prestwood, \& Raisz, 2000; Laughlin, Barrett-Connor, \& Jaclyn, 2008; Zitmann, Faber, \& Nieschlag, 2006; Selvin et al., 2007) These various concerns have led to increased interest worldwide in LOH syndrome (Nieschla et al., 2006).

Among middle-aged men with low testosterone levels, the degrees of physical and psychological symptoms and sexual disorders are different (Rivas, Mulkey, Lado-Abeal, \& Yarbrough, 2017). Considering the advances in methods for diagnosis and treatment of $\mathrm{LOH}$ syndrome, men with any symptoms of LOH syndrome should be recommended to visit a hospital. However, many men are reluctant to visit a hospital and receive appropriate treatment (Corona, Vignozzi, Sforza, \& Maggi, 2013). The strategies for coping with male climacteric symptoms in men who do not visit a hospital have not been clarified.

Ichioka (Ichioka et al., 2006) reported that there were no significant differences in AMS scores for somatic and psychological symptoms by age in 2111 men who underwent health screening. However, approximately $50 \%$ of men in their 40s had moderate or severe symptoms in the sexual subscore. Liu et al. reported that the 5078 Chinese men aged 40 years-79 years old were analyzed by AMS and free testosterone levels, and found a significant decrease in free testosterone with age $(p<0.01)$ and a significant negative association with the 
presence of at least three sexual symptoms $(p=0.03)$ (Liu et al., 2021). We previously reported that the proportion of men who reported male climacteric symptoms in rotating night shift workers, increased with advance of age. There were significant age-dependent differences in AMS scores for somatic symptoms and sexual symptoms (Kubo, Yasui, Matsuura, \& Tomotake, 2019).

As many health problems such as disorders of the cardiovascular and gastrointestinal systems, related to shift work have reported for decades (Smith et al., 2005; Torquati, Mielke, Brown, \& Kolbe-Alexander, 2018) However, few studies have examined the Male climacteric symptoms for night shift workers.

Moreover, it has not been clarified how shift workers cope with these symptoms. Although working women with climacteric symptoms are generally supported (Matsuzaki, Uemura, \& Yasui, 2016; Iioka, 2010), As the wellbeing of the night-shift workers exert a significant impact on productivity, it is highly important to explore coping strategies.

This study aimed to clarify how male rotating night shift workers cope with male climacteric symptoms by AMS and whether strategies used for coping with symptoms are different depending on age.

\section{Method}

\subsection{Study Design}

A cross-sectional survey was conducted in 2017. An unsigned self-reported questionnaire survey was planned for male rotating night shift workers over the age of 20 years, including those working all or some of the hours from 10:00 p.m. to 5:00 a.m., in manufacturing companies in Japan.

\subsection{Study Participants and Sampling Procedure}

We requested the managers of general affairs or occupational health nurses in 33 companies for cooperation in the study, and we distributed the questionnaires to 1891 Japanese men who work in rotating night shift during the period from March to May in 2017. The number of employees of the companies ranged from 50 to over 1000 We firstly distributed an explanation sheet and a consent form to the manager in the company, and we received written informed consent after explanation regarding the study. The study targeted only men who agreed to participate after explanation by using the explanation sheet through the manager in the company. The explanation sheet included an explanation about the respect for autonomy and anonymization of personal data. The questionnaires were obtained from collection boxes or by mail.

\subsection{Data Analysis}

Baseline characteristics were analyzed by descriptive statistics. Comparisons of leisure activities among age groups were done by the chi-square test. We calculated the proportion of men who coped with each symptom and compared the presence of coping strategies with male climacteric symptoms among five age groups (20s to $60 \mathrm{~s}$ ) by using the chi-square test. The presence of coping strategies was used as a dependent variable and age was used as an independent variable in the analysis. Items that were found to have significant differences among the age groups were analyzed by residual analysis. Differences in the proportions of men who coped with symptoms according to age were calculated. When residual values after adjustment were less than or more than $1.96, p<0.05$ were considered to be statistically significant, and when residual values after adjustment were less than or more than $2.58, p<0.01$ were considered to be statistically significant. For symptoms and coping strategies for which significant differences in frequencies were detected among age groups, the degrees of symptoms in the age groups were also analyzed by the Kruskal-Wallis test.

All statistical analyses were conducted using SPSS statistics, version 25 (IBM Corp.).

\subsection{Ethical Approval}

This study was approved by the Research Ethics Committee of Tokushima University Hospital (2745). An explanation sheet and a consent form were sent to the manager of each company, and written informed consent was obtained after an explanation regarding the study. We then recruited participants through the general affairs department of each company and health management center. The subjects were only men who agreed to participate after receiving an explanation of the study from the manager of the company. The explanation sheet included an explanation about the respect for autonomy and anonymization of personal data.

\section{Results}

\subsection{Socio-Demographics}

Of the 1,891 subjects recruited, 1,561 responded (response rate of $82.5 \%$ ). We excluded 26 participants who were under the age of 20 years, 11 participants who were fixed night shift workers and 24 participants for whom ages were unknown, and we analyzed data for 1500 rotating night shift workers. Baseline characteristics including age distribution, duration of shiftwork and type of shiftwork are shown in Table 1. (Table 1) 
Table 1. Baseline Characteristics

\begin{tabular}{|c|c|c|c|}
\hline & & Number & Proportion (\%) \\
\hline Age (years) & $20-29$ & 451 & 29.7 \\
\hline \multirow[t]{5}{*}{$(n=1524)$} & $30-39$ & 237 & 15.6 \\
\hline & $40-49$ & 382 & 25.1 \\
\hline & $50-59$ & 337 & 22.1 \\
\hline & $\geq 60$ & 93 & 6.1 \\
\hline & Missing & 24 & 1.6 \\
\hline Duration of shiftwork & $<10$ & 570 & 38 \\
\hline (years) & 1119 & 270 & 18 \\
\hline \multirow[t]{4}{*}{$(n=1500)$} & $20-29$ & 319 & 21.3 \\
\hline & $30-39$ & 198 & 13.2 \\
\hline & $\geq 40$ & 129 & 8.6 \\
\hline & Missing & 14 & 0.9 \\
\hline Types of shift & Three-shift work & 1110 & 74 \\
\hline \multirow[t]{3}{*}{$(n=1500)$} & Two-shift work & 343 & 22.9 \\
\hline & Others & 46 & 3.1 \\
\hline & Missing & 1 & 0.1 \\
\hline Employment status & Regular employee & 1301 & 86.7 \\
\hline \multirow[t]{5}{*}{$(\mathrm{n}=1500)$} & Contract employee & 117 & 7.8 \\
\hline & Dispatched employee & 31 & 2.1 \\
\hline & Part-time workers & 7 & 0.5 \\
\hline & Others & 31 & 2.1 \\
\hline & Missing & 13 & 0.9 \\
\hline Ages of men living with their wives & $20-29$ & 125 & 27.8 \\
\hline (years) & $30-39$ & 146 & 61.6 \\
\hline \multirow[t]{4}{*}{$(\mathrm{n}=915)$} & $40-49$ & 278 & 72.8 \\
\hline & $50-59$ & 285 & 84.6 \\
\hline & $\geq 60$ & 80 & 86 \\
\hline & Missing & 1 & 1 \\
\hline Leisure activities & Shopping & 642 & 42.8 \\
\hline (multiple answers allowed) & $\begin{array}{l}\text { Playing TV games and using a smartphone and } \\
\text { computer }\end{array}$ & 613 & 40.9 \\
\hline \multirow[t]{10}{*}{$(\mathrm{n}=1500)$} & Spending time with family & 537 & 35.8 \\
\hline & Exercising & 437 & 29.1 \\
\hline & Playing pinball games and bicycle races & 382 & 25.5 \\
\hline & Socializing & 294 & 19.6 \\
\hline & Watching movies & 258 & 17.2 \\
\hline & Watching sports & 195 & 13.0 \\
\hline & Listening to music & 185 & 12.3 \\
\hline & Reading books & 134 & 8.4 \\
\hline & Doing home carpentry & 61 & 4.1 \\
\hline & Others & 350 & 23.3 \\
\hline
\end{tabular}


Table 2. Top three strategies for coping with male climacteric symptoms

\begin{tabular}{|c|c|c|c|c|c|c|c|c|c|c|}
\hline & & First ranking & $\%$ & number & Second ranking & $\%$ & number & Third ranking & $\%$ & number \\
\hline \multirow{8}{*}{$\begin{array}{l}\text { Somatic } \\
\text { symptoms }\end{array}$} & $\begin{array}{l}\text { Decline in the feeling of } \\
\text { general well-being }\end{array}$ & Ignoring and tolerating symptoms & 33.0 & $222 / 673$ & Taking a rest & 32.4 & $218 / 673$ & Talking with wife & 21.6 & $145 / 672$ \\
\hline & Joint pain and muscular ache & Ignoring and tolerating symptoms & 34.0 & $234 / 688$ & Taking a rest & 26.2 & $180 / 687$ & $\begin{array}{l}\text { Consulting a family or } \\
\text { occupational physician }\end{array}$ & 19.5 & $134 / 688$ \\
\hline & Excessive sweating & Ignoring and tolerating symptoms & 58.9 & $119 / 202$ & Taking a rest & 19.3 & $39 / 202$ & Talking with wife & 9.9 & $20 / 202$ \\
\hline & & & & & & & & $\begin{array}{l}\text { Searching on the } \\
\text { Internet }\end{array}$ & 9.9 & $20 / 202$ \\
\hline & Sleep problems & Ignoring and tolerating symptoms & 51.0 & $337 / 661$ & Taking a rest & 25.6 & $170 / 663$ & Talking with wife & 11.6 & $77 / 663$ \\
\hline & $\begin{array}{l}\text { Increased need for sleep, often } \\
\text { feeling tired }\end{array}$ & Ignoring and tolerating symptoms & 47.9 & $377 / 787$ & Taking a rest & 40.6 & $319 / 786$ & Talking with wife & 9.8 & $77 / 787$ \\
\hline & $\begin{array}{l}\text { Physical exhaustion / lacking } \\
\text { vitality }\end{array}$ & Ignoring and tolerating symptoms & 48.4 & $333 / 688$ & Taking a rest & 30.9 & $212 / 687$ & Exercising & 12.8 & $88 / 688$ \\
\hline & Decrease in muscular strength & Ignoring and tolerating symptoms & 46.4 & $313 / 674$ & Exercising & 30.3 & $204 / 673$ & Taking a rest & 15.9 & $107 / 672$ \\
\hline \multirow{5}{*}{$\begin{array}{l}\text { Psychological } \\
\text { symptoms }\end{array}$} & Irritability & Ignoring and tolerating symptoms & 53.7 & $347 / 646$ & Taking a rest & 25.3 & $163 / 645$ & Enjoying hobbies & $\overline{20.1}$ & $130 / 647$ \\
\hline & Nervousness & Ignoring and tolerating symptoms & 57.2 & $253 / 442$ & Taking a rest & 24.0 & $106 / 442$ & Enjoying hobbies & 12.0 & $53 / 442$ \\
\hline & Anxiety & Ignoring and tolerating symptoms & 54.4 & $186 / 342$ & Taking a rest & 23.1 & $79 / 342$ & Talking with wife & 9.6 & $33 / 342$ \\
\hline & Depressive mood & Ignoring and tolerating symptoms & 53.0 & $258 / 487$ & Taking a rest & 23.2 & $113 / 488$ & Enjoying hobbies & 16.4 & $80 / 488$ \\
\hline & $\begin{array}{l}\text { Feeling burnt out, having hit } \\
\text { rock-bottom }\end{array}$ & Ignoring and tolerating symptoms & 64.9 & $131 / 202$ & Taking a rest & 18.8 & $38 / 202$ & Talking with wife & 8.4 & $17 / 202$ \\
\hline \multirow{5}{*}{$\begin{array}{l}\text { Sexual } \\
\text { symptoms }\end{array}$} & $\begin{array}{l}\text { Feeling that you have passed } \\
\text { your peak }\end{array}$ & Ignoring and tolerating symptoms & 59.8 & $196 / 328$ & Taking a rest & 16.2 & $53 / 328$ & Talking with wife & 10.3 & $34 / 329$ \\
\hline & Decrease in beard growth & Ignoring and tolerating symptoms & 67.0 & $77 / 115$ & Taking a rest & 11.3 & $13 / 115$ & Talking with wife & 7.8 & $9 / 115$ \\
\hline & $\begin{array}{l}\text { Decrease in ability/frequency } \\
\text { to perform sexually }\end{array}$ & Ignoring and tolerating symptoms & 68.1 & $241 / 354$ & Taking a rest & 13.0 & $46 / 354$ & Talking with wife & 6.8 & $24 / 354$ \\
\hline & $\begin{array}{l}\text { Decrease in the number of } \\
\text { morning erections }\end{array}$ & Ignoring and tolerating symptoms & 68.8 & $245 / 356$ & Taking a rest & 12.1 & $43 / 356$ & Talking with wife & 6.4 & $23 / 357$ \\
\hline & Decrease in sexual desire/libido & Ignoring and tolerating symptoms & 13.0 & $39 / 299$ & Taking a rest & 2.7 & $8 / 299$ & Enjoying hobbies & 1.7 & $5 / 299$ \\
\hline
\end{tabular}


Table 3-1. Proportions of men with the top three strategies for coping with physical symptoms according to ages

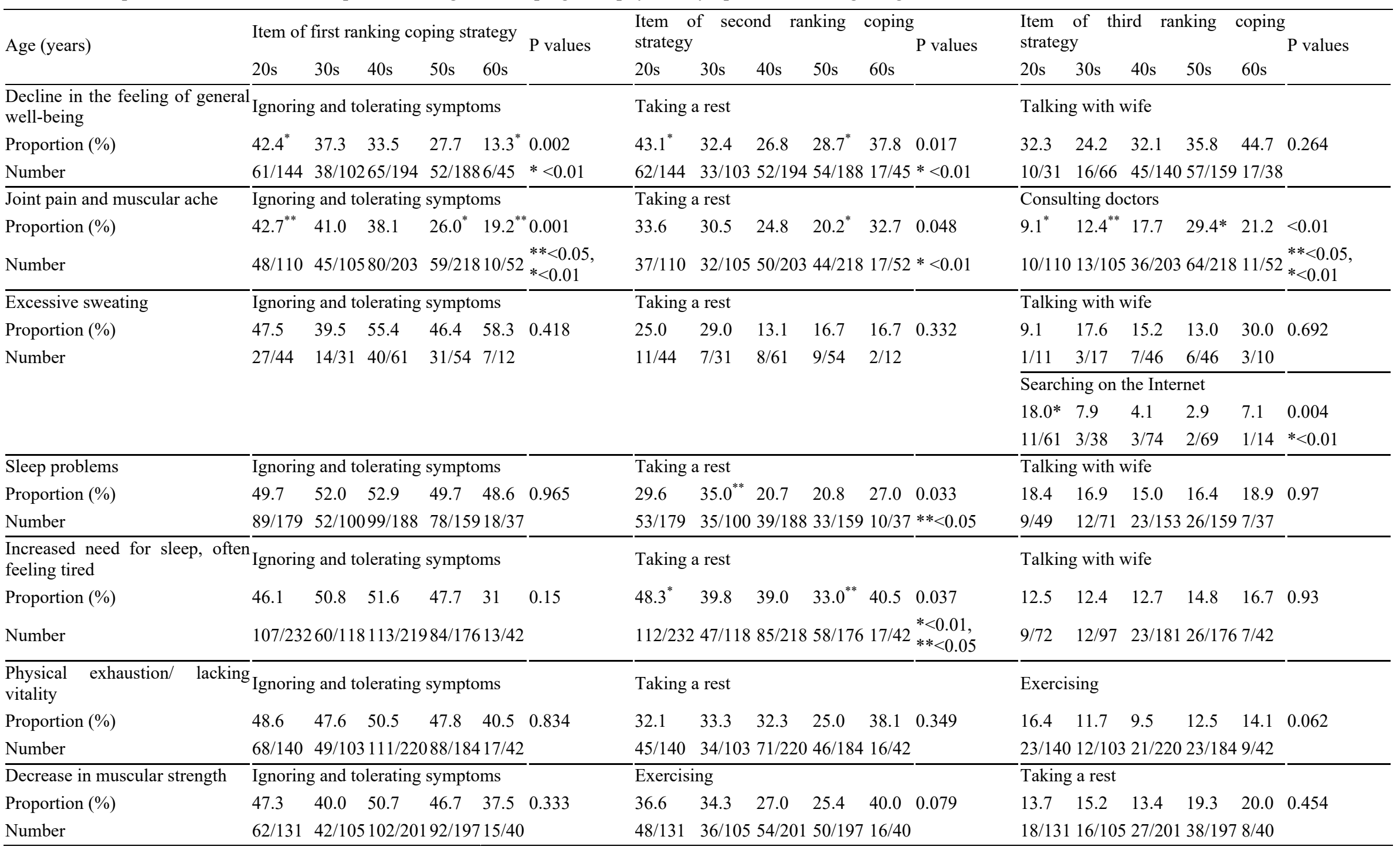

* and **: significant according to residual analysis. 
Table 3-2. Proportions of men with the top three strategies for coping with psychological symptoms according to ages

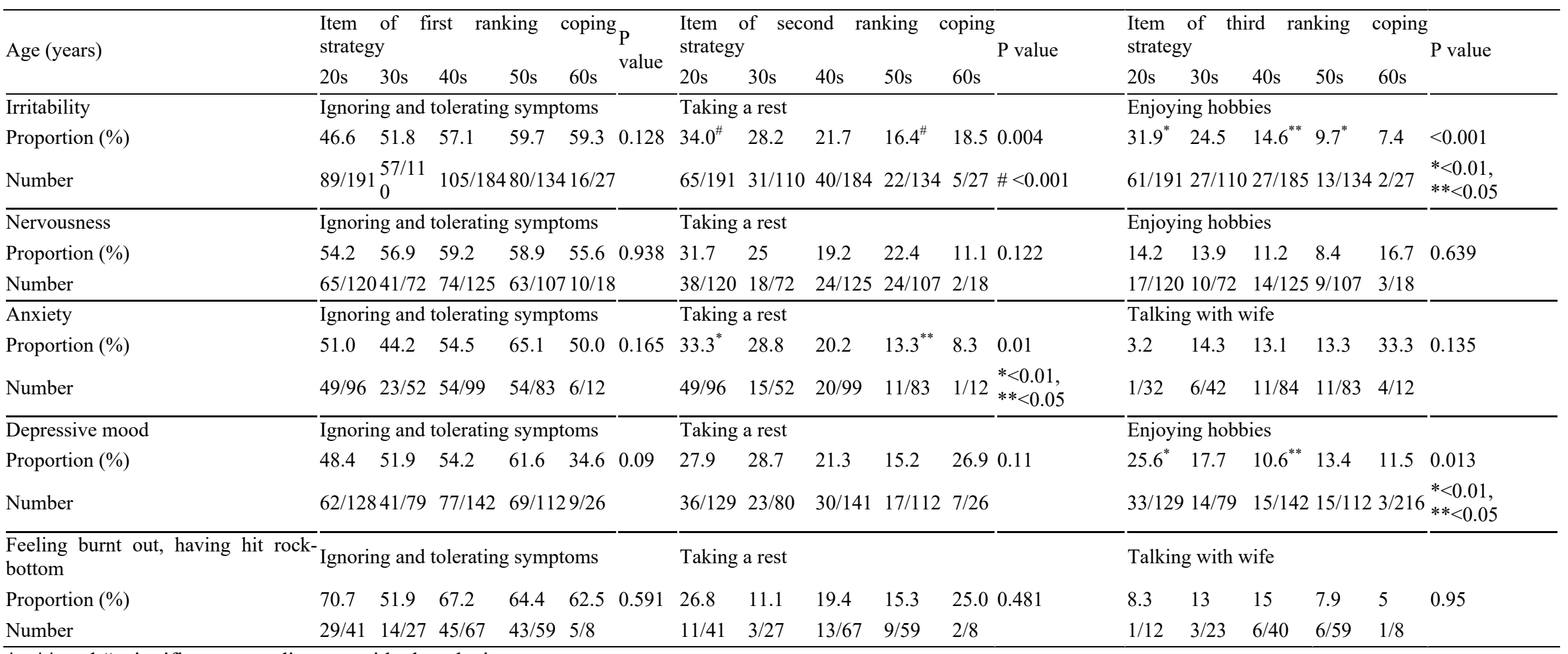

*, ** and \#: significant according to residual analysis 
Table 3-3. Proportions of men with the top three strategies for coping with psychological symptoms according to ages

\begin{tabular}{|c|c|c|c|c|c|c|c|c|c|c|c|c|c|c|c|c|c|c|}
\hline \multirow[b]{2}{*}{ Age (years) } & \multicolumn{2}{|c|}{$\begin{array}{l}\text { Item of } \\
\text { strategy }\end{array}$} & first & ranking & \multicolumn{2}{|c|}{ coping } & \multicolumn{2}{|c|}{$\begin{array}{l}\text { Item of } \\
\text { strategy }\end{array}$} & \multirow{2}{*}{$\begin{array}{l}\text { second } \\
40 \text { s }\end{array}$} & \multirow{2}{*}{$\begin{array}{c}\text { ranking } \\
50 \mathrm{~s}\end{array}$} & \multicolumn{2}{|c|}{ coping } & \multicolumn{2}{|c|}{$\begin{array}{l}\text { Item of } \\
\text { strategy }\end{array}$} & third & ranking & coping & \multirow[b]{2}{*}{$\begin{array}{l}P \\
\text { value }\end{array}$} \\
\hline & $20 \mathrm{~s}$ & $30 \mathrm{~s}$ & $40 \mathrm{~s}$ & $50 \mathrm{~s}$ & $60 \mathrm{~s}$ & $P$ value & $20 \mathrm{~s}$ & $30 \mathrm{~s}$ & & & $60 \mathrm{~s}$ & $\begin{array}{l}\mathrm{P} \\
\text { value }\end{array}$ & $20 \mathrm{~s}$ & $30 \mathrm{~s}$ & $40 \mathrm{~s}$ & $50 \mathrm{~s}$ & $60 \mathrm{~s}$ & \\
\hline Feeling that you have passed your peak & \multicolumn{5}{|c|}{ Ignoring and tolerating symptoms } & & \multicolumn{3}{|c|}{ Taking a rest } & & & & \multicolumn{4}{|c|}{ Talking with wife } & & \\
\hline Proportion $(\%)$ & 60 & 56.8 & 69.9 & 56.3 & 40.7 & 0.056 & 22.9 & 18.2 & 18.4 & 12.6 & 11.1 & 0.508 & 23.1 & 8.1 & 5.8 & 14.3 & 18.5 & 0.104 \\
\hline number & $21 / 35$ & $25 / 44$ & $+72 / 103$ & $67 / 119$ & $11 / 27$ & & $8 / 35$ & $8 / 44$ & $19 / 103$ & $15 / 119$ & $3 / 27$ & & $3 / 13$ & $3 / 37$ & $6 / 103$ & $17 / 119$ & $5 / 27$ & \\
\hline Decrease in beard growth & \multicolumn{5}{|c|}{ Ignoring and tolerating symptoms } & & \multicolumn{3}{|c|}{ Taking a rest } & & & & \multicolumn{4}{|c|}{ Talking with wife } & & \\
\hline Proportion $(\%)$ & 55.6 & 50.0 & 74.4 & 67.5 & 66.7 & 0.448 & 22.2 & 21.4 & 14.0 & 5.0 & 0 & 0.488 & 0 & 14.3 & 4.7 & 7.5 & 22.2 & 0.419 \\
\hline number & $5 / 9$ & $7 / 14$ & $32 / 43$ & $27 / 40$ & $6 / 9$ & & $2 / 9$ & $3 / 14$ & 7.43 & $2 / 40$ & $0 / 9$ & & $0 / 2$ & $2 / 14$ & $2 / 43$ & $3 / 40$ & $2 / 9$ & \\
\hline $\begin{array}{l}\text { Decrease in ability and frequency to } \\
\text { sexually }\end{array}$ & \multicolumn{5}{|c|}{ Ignoring and tolerating symptoms } & & \multicolumn{3}{|c|}{ Taking a rest } & & & & \multicolumn{4}{|c|}{ Talking with wife } & & \\
\hline Proportion (\%) & 71.9 & 65.2 & 68.1 & 68.1 & 67.9 & 0.984 & 3.1 & 17.4 & 16.8 & 9.6 & 17.9 & 0.139 & 0 & 4.7 & 8.8 & 7.4 & 7.1 & 0.787 \\
\hline number & $23 / 32$ & $30 / 46$ & $677 / 113$ & $92 / 135$ & $19 / 28$ & & $1 / 32$ & $8 / 46$ & $19 / 113$ & $13 / 135$ & $5 / 28$ & & $0 / 11$ & $2 / 43$ & $10 / 113$ & $10 / 135$ & $2 / 28$ & \\
\hline Decrease in the number of morning erections & \multicolumn{5}{|c|}{ Ignoring and tolerating symptoms } & & \multicolumn{3}{|c|}{ Taking a rest } & & & & \multicolumn{4}{|c|}{ Talking with wife } & & \\
\hline Proportion (\%) & 69.7 & 57.8 & 72.2 & 70.2 & 65.6 & 0.486 & 6.1 & 17.8 & 13.0 & 10.7 & 12.5 & 0.584 & 0 & 8.9 & 7.8 & 6.1 & 6.3 & 0.845 \\
\hline number & $23 / 33$ & $26 / 45$ & $83 / 115$ & $92 / 131$ & $21 / 32$ & & $2 / 33$ & $8 / 45$ & $15 / 115$ & $14 / 131$ & $4 / 32$ & & $0 / 11$ & $4 / 45$ & $9 / 115$ & $8 / 131$ & $2 / 32$ & \\
\hline Decrease in sexual desire/libido & \multicolumn{5}{|c|}{ Ignoring and tolerating symptoms } & & \multicolumn{3}{|c|}{ Taking a rest } & & & & \multicolumn{4}{|c|}{ Enjoying hobbies } & & \\
\hline Proportion $(\%)$ & $3.1^{*}$ & 5.4 & 17.9 & $27.6^{*}$ & 22.2 & $<0.001$ & 0.8 & 2.7 & 3.6 & 4.6 & 5.6 & 0.451 & 0 & 0 & 0 & 4.3 & 5.4 & 0.015 \\
\hline number & $4 / 129$ & $2 / 37$ & $5 / 28$ & $24 / 87$ & $4 / 18$ & $\begin{array}{l}* \\
<0.01\end{array}$ & $1 / 129$ & $1 / 37$ & $1 / 28$ & $4 / 87$ & $1 / 18$ & & $0 / 129$ & $0 / 37$ & $0 / 28$ & $5 / 87$ & $0 / 18$ & \\
\hline
\end{tabular}

*: significant according to residual analysis 
The proportion of men living with their wives increased with the advance of age. Shopping was the most common leisure activity followed by playing video games, using smartphones and personal computers, and relaxing with the family. The proportion of men who played video games, used smartphones and computers, did exercise, watched movies, listened to music and read books was high in men in their $20 \mathrm{~s}(\mathrm{p}<0.01)$. The proportions of men who did shopping and relaxed with their family as leisure activities were not different in the age groups.

\subsection{Coping Strategies for Male Climacteric Symptoms}

The top 3 coping strategies for 17 male climacteric symptoms by AMS are shown in Table 2. (Table2)

The most frequent coping strategy for all symptoms was simply to try to ignore and tolerate the symptoms. The second-most frequent coping strategies were to take time to relax for 16 symptoms and to exercise for the symptom of decrease in muscle strength. The third-most frequent coping strategies were talking with their wives, consulting a doctor, exercising, enjoying their hobbies and using the Internet.

Since coping strategies may differ depending on age, differences in the top 3 strategies for coping with symptoms in the different age groups were examined (Table 3 ).

The proportions of men who tried to ignore and tolerate the symptom of decline in the feeling of general wellbeing were high in men in their $20 \mathrm{~s}$ and low in men in their $60 \mathrm{~s}$. The proportions of men who took a rest for the symptom of decline in the feeling of general well-being were high in men in their 20 s and low in men in their 40 s.

The proportions of men who tried to ignore and tolerate joint and muscular pain were high in men in their 20s and low in men in their 50s and 60s. The proportion of men who took a rest for the symptom of joint and muscular pain was low in men in their $50 \mathrm{~s}$. The proportions of men who consulted a family doctor or occupational doctor for the symptom of joint and muscular pain were low in men in their 20s and 30s and high in men in their 50s. The proportion of men who spent time using the Internet as a strategy for coping with excessive sweats was high in men in their 20s. The proportions of men who took a rest for the symptoms of increased need for sleep and often feeling tired were high in men in their 20s and low in men in their 50s. The proportions of men who took a rest for the symptom of irritability and anxiety were high in men in their 20s and low in men in their 50s. The proportions of men who took time to enjoy their hobbies as a strategy for coping with depressive mood were high in men in their 20s and low in men in their 40s.

For symptoms that showed significant differences in frequency depending on age, the degrees of these symptoms in the different age groups were examined. Only the degree of irritability in men who took a rest as a coping strategy differed significantly among the age groups. The proportion of men who had severe irritability was high in young men and the proportion of men who had mild irritability was high in elderly men $(p=0.012)$.

\section{Discussion}

\subsection{Frequent coping Strategies with Male Climacteric Symptoms}

The most frequent coping with physical symptoms was simply to try to ignore and tolerate the symptoms. However, men consulted a family doctor or occupational doctor for symptoms in specific sites such as joint and muscle pain. For coping with psychological symptoms, the most frequent strategy was trying to ignore and tolerate the symptoms and the second-most frequent strategy was taking a rest. Men in their 20s tended to spend time enjoying their hobbies for coping with irritability and anxiety. Spending time enjoying hobbies is a common strategy used for improving psychological symptoms, but it was not included in the top three strategies for coping with physical symptoms. Synder et al. reported that coping by pleasurable distractions might be particularly effective in the face of uncontrollable stressors (Synder, 2001). The proportion of men who ignored sexual dysfunction was high in the present study. Sexual dysfunction might not be recognized as a male climacteric symptom. It has been reported that the level of awareness of andropause was very low despite the fact that many men over the age of 40 years have experienced symptoms due to andropause (Samipoor Pakseresht, Rezasoltani, \& Leili, 2017). Although a statistically significant difference was found between strategies for coping with sexual symptoms and ages, the statistical significance is considered to be weak because of the small number of responses to questions on sexual symptoms.

\subsection{Differences in Coping Strategies with Aging}

The proportions of men who tried to ignore and tolerate psychological symptoms were high in all age groups. Men may also not recognize psychological symptoms as male climacteric symptoms. Even if they feel anxiety about these symptoms, they may not know which clinical department they should visit. Among physical symptoms, the proportions of men who ignored the symptom of decline in the feeling of general well-being were high in men in their $20 \mathrm{~s}$ and low in men in their 60 s. Young men may feel that the degree of their symptoms is 
mild and it is not necessary to visit a hospital. It has been reported that working men do not visit general physicians unless they have a severe health problem and have to stop working (Hale, Grogan, \& Willott, 2010). Working men do not have time for visiting hospitals. Although rotating shift workers can visit hospitals during the day, they may lack the motivation for visiting hospitals because of sleepiness and general fatigue. The proportions of men who ignored the symptom of joint and muscular pain were low in men in their 50s and 60s. Men in their 50s and 60s may decide to not endure symptoms in order to prevent worsening of mild symptoms since they might consider that deterioration of symptoms would affect their work in the factory.

The proportions of men who consulted a family doctor or occupational doctor about a decline in the feeling of general well-being were high in men in their 50s and low in men in their 20s. Many men in their 20s do not have family doctors, and they may be reluctant to visit a hospital. Men in their 50s, on the other hand, may decide to visit a hospital since their worsening health condition might affect their job status in night shift work. Since many men in their 50 s would already have visited hospitals for their poor conditions or for various diseases, they may not hesitate to visit a hospital. In addition, men in their 50s may have some anxiety about their health. Rotating shift workers in the manufacturing industry are likely to work in a standing position and to use the musculoskeletal system including upper and lower limbs. Musculoskeletal system-related symptoms may affect their work at the workplace. It has been reported that the severity and functional disability of low back pain were correlated with age and job tenure among workers (Al-Salameen, Abugad, \& Al-Otaib, 2019; Sterud \& Tynes, 2013).

We showed that men in their 20s were likely to search on the Internet to cope with the symptoms of decline in the feeling of general well-being and severe sweats. Sweats in women are well-known female climacteric symptoms, but sweats in men have not been recognized as male climacteric symptoms. It has been reported that young people were more frequent users of the Internet for obtaining health information and that young people felt that searching on the Internet was important before visiting hospitals (Turan, Kaya, \& Aydin, 2015; McMullan, 2006).

There were high proportions of men in their 20s who took a rest for coping with the symptom of decline in the feeling of general well-being and the symptom of irritability and anxiety. Men in their 20 s might not have any coping strategies due to their lack of experience at their workplaces. Men in their 50s may use individual coping strategies for maintenance of a healthy psychological state based on their own experiences that would enable them to continue to work as rotating shift workers for a long time.

It has been reported that the prevalence of insomnia and other sleep problems in shift workers was higher than that in non-shift workers (Doi, 2005). We showed that the proportions of men who took time to relax to cope with the symptom of increased need for sleep and often feeling tired were high in men in their 20s and low in men in their $50 \mathrm{~s}$. Men in their 20s may need to take a rest since the proportion of men whose symptoms were moderate or severe was higher in men in their 20s than in men in their 50s. Rotating shift workers in their 20s may compensate for their lack of sleep at night by sleeping more during the day. There were men who ignored sleep problems in all age groups. Night rotating shift workers may understand that working against the circadian rhythm induces these symptoms.

Men in their 50s and 60s tended to talk with their wives as a coping strategy. It has been reported that rotating shift workers in their 50s and 60s were able to continue their jobs for a long time due to the support of their wives (Kubo \& Tada, 2014). It has been shown that talking with their wives and advice given by wives encourage men to consult doctors (Ministry of Health and Welfare, 2017).

\subsection{Occupational Health Nurses}

Occupational health nurses can also provide information on self-diagnosis of male climacteric symptoms, information on outpatient clinics for male climacteric symptoms and information on LOH syndrome. However, it might be difficult for male workers to consult with nurses about sexual dysfunction unlike physical symptoms since most of the occupational health nurses in companies are females. It is important for occupational health nurses to have knowledge for assessment of male climacteric symptoms. It has been reported that a large number of men with LOH syndrome were obese and had lifestyle-related diseases (Zarotsky et al., 2014). Occupational health nurses can provide appropriate suggestions including suggestions for maintenance of appropriate body weight and improvement of lifestyle-related diseases. In addition, education regarding male climacteric symptoms by occupational health nurses may be needed for workers. If workers have an awareness of male climacteric symptoms and take appropriate coping strategies, deterioration of various symptoms including sarcopenia, osteoporosis and cardiovascular diseases caused by LOH syndrome may be prevented.

\subsection{Study Limitations}

This study has several limitations. There may be selection bias due to missing data. Some of the participants did not answer the question about sexual symptoms. In addition, it cannot be determined whether sleep problems are 
related to male climacteric symptoms or circadian rhythm disturbance. A passive coping strategy by drinking alcohol should also be considered (Smith et al., 2005). The accessibility to occupational physicians might be different since the sizes of companies varied. Finally, information such as information on past history and present illness was not included in the questionnaire because of the protection of personal data. Therefore, the possibility that diseases other than male climacteric symptoms were included cannot be ruled out. This is another limitation of the questionnaire survey without biological data.

\section{Conclusion}

The most frequent strategy used by rotating shift workers for coping with male climacteric symptoms by AMS was to ignore and tolerate the symptoms and the second-most frequent strategy was taking a rest. There was a difference in strategies for coping with symptoms depending on age, and there were high proportions of men in their 20s who ignored and tolerated the symptom of decline in the feeling of general well-being and the symptom of joint and muscular pain. The proportions of men who took a rest to cope with irritability and anxiety were high in men in their 20 s and low in men in their 50 s.

\section{Acknowledgments}

The authors would like to express our gratitude to participants, managers of general affairs and occupational health nurses. We are also grateful to Professor Iwamoto.

\section{Competing Interests Statement}

The authors declare that there are no competing conflicts of interest.

\section{References}

Al-Salameen, A. H., Abugad, H. A., \& Al-Otaibi, S. T. (2019). Low back pain among workers in a paint factory. Saudi journal of medicine \& medical sciences, 7(1), 33. https://doi.org/10.4103/sjmms.sjmms_81_17

Corona, G., Vignozzi, L., Sforza, A., \& Maggi, M. (2013). Risks and benefits of late onset hypogonadism treatment: an expert opinion. The world journal of men's health, 31(2), 103-125. https://doi.org/10.5534/wjmh.2013.31.2.103

Doi, Y. (2005). An epidemiologic review on occupational sleep research among Japanese workers. Industrial health, 43(1), 3-10. https://doi.org/10.2486/indhealth.43.3

Hale, S., Grogan, S., \& Willott, S. (2010). Male GPs' views on men seeking medical help: A qualitative study. British Journal of Health Psychology, 15(4), 697-713. https://doi.org/10.1348/135910709X479113

Heinemann, L. A., Saad, F., Zimmermann, T., Novak, A., Myon, E., Badia, X., ... \& Giroudet, C. (2003). The Aging Males' Symptoms (AMS) scale: update and compilation of international versions. Health and quality of life outcomes, 1(1), 1-5. https://doi.org/10.3109/13685539909003173

Ichioka, K., Nishiyama, H., Yoshimura, K., Itoh, N., Okubo, K., \& Terai, A. (2006). Aging males' symptoms scale in Japanese men attending a multiphasic health screening clinic. Urology, 67(3), 589-593. https://doi.org/10.1016/j.urology.2005.09.057

Iioka, Y. (2010). Mental and physical changes experienced by premenopausal women and coping methods. Journal of Japanese Society of Psychosomatic Obstetrics and Gynecology, 15, 237-247.

Kenny, A. M., Prestwood, K. M., \& Raisz, L. G. (2000). Short-term effects of intramuscular and transdermal testosterone on bone turnover, prostate symptoms, cholesterol, and hematocrit in men over age 70 with low testosterone levels. Endocrine research, 26(2), 153-168. https://doi.org/10.3109/07435800009066159

Kubo, S., \& Tada, T. (2014) Work-life difficulties and coping strategies of male night-shift workers. Journal of Shikoku Public Health Society, 5 (1), 133-139.

Kubo, S., Yasui, T., Matsuura, Y., \& Tomotake, M. (2020). Differences in male climacteric symptoms with aging among rotating night shift workers. The Aging Male, 23(5), 995-1003. https://doi.org/10.1080/13685538.2019.1650264

Laughlin, G. A., Barrett-Connor, E., \& Bergstrom, J. (2008). Low serum testosterone and mortality in older men. The Journal of Clinical Endocrinology \& Metabolism, 93(1), 68-75. https://doi.org/10.1210/jc.2007-1792

Liu, Y. J., Shen, X. B., Yu, N., Shang, X. J., Gu, Y. Q., Zuo, L. D., ... \& Zhou, Y. Z. (2021). Prevalence of lateonset hypogonadism among middle-aged and elderly males in China: results from a national survey. Asian Journal of Andrology, 23(2), 170. https://doi.org/10.4103/aja.aja_59_20

Lyne, K., \& Roger, D. (2000). A psychometric re-assessment of the COPE questionnaire. Personality and Individual Differences, 29(2), 321-335. https://doi.org/10.1016/S0191-8869(99)00196-8 
Matsuzaki, K., Uemura, H., \& Yasui, T. (2016). Differences in coping with menopausal symptoms in nurses and general workers in Japan. Maturitas, 86, 45-52. https://doi.org/10.1016/j.maturitas.2016.01.010

McMullan, M. (2006). Patients using the Internet to obtain health information: how this affects the patienthealth professional relationship. Patient education and counseling, 63(1-2), 24-28. https://doi.org/10.1016/j.pec.2005.10.006

Ministry of Health, Labour and Welfare. Patient's Behavior Survey 2017 Outline of Result. Retrieved July 29, 2019, from https://www.mhlw.go.jp/toukei/saikin/hw/jyuryo/17/dl/gaikyo-all-g.pdf

Nieschlag, E., Swerdloff, R., Behre, H. M., Gooren, L. J., Kaufman, J. M., Legros, J. J., ... \& Wu, F. C. (2005). Investigation, treatment and monitoring of late-onset hypogonadism in males. The Aging Male, 8(2), 56-58. https://doi.org/10.2164/jandrol.05047

Rivas, A. M., Mulkey, Z., Lado-Abeal, J., \& Yarbrough, S. (2014, October). Diagnosing and managing low serum testosterone. In Baylor University Medical Center Proceedings (Vol. 27, No. 4, pp. 321-324). Taylor \& Francis. https://doi.org/10.1080/08998280.2014.11929145

Samipoor, F., Pakseresht, S., Rezasoltani, P., \& Kazemnajad Leili, E. (2017). Awareness and experience of andropause symptoms in men referring to health centers: a cross-sectional study in Iran. The Aging Male, 20(3), 153-160. https://doi.org/10.1080/13685538.2017.1298586

Selvin, E., Feinleib, M., Zhang, L., Rohrmann, S., Rifai, N., Nelson, W. G., ... \& Platz, E. A. (2007). Androgens and diabetes in men: results from the Third National Health and Nutrition Examination Survey (NHANES III). Diabetes care, 30(2), 234-238. https://doi.org/10.2337/dc06-1579

Smith, L., Tanigawa, T., Takahashi, M., Mutou, K., Tachibana, N., Kage, Y., \& Iso, H. (2005). Shiftwork locus of control, situational and behavioural effects on sleepiness and fatigue in shiftworkers. Industrial health, 43(1), 151-170. https://doi.org/10.2486/indhealth.43.151

Sterud, T., \& Tynes, T. (2013). Work-related psychosocial and mechanical risk factors for low back pain: a 3year follow-up study of the general working population in Norway. Occupational and environmental medicine, 70(5), 296-302. https://doi.org/10.1136/oemed-2012-101116

Snyder, C. R. (Ed.). (2001). Coping with stress: Effective people and processes. Oxford University Press. https://doi.org/10.1093/med:psych/9780195130447.001.0001

Torquati, L., Mielke, G. I., Brown, W. J., \& Kolbe-Alexander, T. (2018). Shift work and the risk of cardiovascular disease. A systematic review and meta-analysis including dose-response relationship. Scandinavian journal of work, environment \& health, 44(3), 229-238. https://doi.org/10.5271/sjweh.3700

Turan, N., Kaya, N., \& Aydın, G. Ö. (2015). Health problems and help seeking behavior at the internet. Procedia-Social and Behavioral Sciences, 195, 1679-1682. https://doi.org/10.1016/j.sbspro.2015.06.248

Zarotsky, V., Huang, M. Y., Carman, W., Morgentaler, A., Singhal, P. K., Coffin, D., \& Jones, T. H. (2014). Systematic literature review of the epidemiology of nongenetic forms of hypogonadism in adult males. Journal of Hormones, 2014. https://doi.org/10.1155/2014/190347

Zitzmann, M., Faber, S., \& Nieschlag, E. (2006). Association of specific symptoms and metabolic risks with serum testosterone in older men. The Journal of Clinical Endocrinology \& Metabolism, 91(11), 4335-4343. https://doi.org/10.1210/jc.2006-0401

\section{Copyrights}

Copyright for this article is retained by the author(s), with first publication rights granted to the journal.

This is an open-access article distributed under the terms and conditions of the Creative Commons Attribution license (http://creativecommons.org/licenses/by/4.0/). 